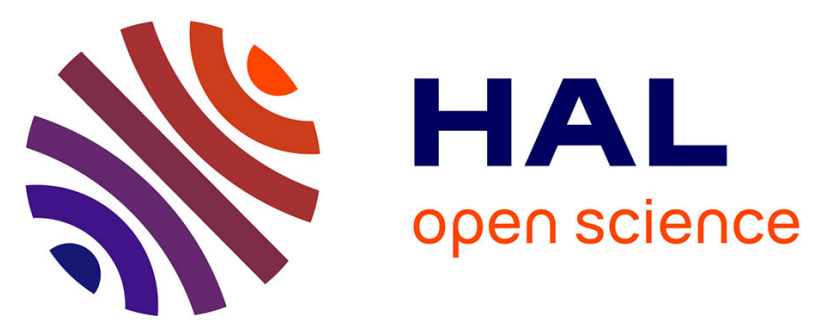

\title{
Smart Algorithm Based on the Optimization of SVR Technique by k-NNR Method for the Prognosis of the Open-Circuit and the Reversed Polarity Faults in a PV Generator
}

\author{
Wail Rezgui, Nadia Kinza Mouss, Leïla-Hayet Mouss, Mohamed Djamel \\ Mouss, Yassine Amirat, Mohamed Benbouzid
}

\section{To cite this version:}

Wail Rezgui, Nadia Kinza Mouss, Leïla-Hayet Mouss, Mohamed Djamel Mouss, Yassine Amirat, et al.. Smart Algorithm Based on the Optimization of SVR Technique by k-NNR Method for the Prognosis of the Open-Circuit and the Reversed Polarity Faults in a PV Generator. International Review on Modelling and Simulations (IREMOS), 2015, 8 (1), pp.18-25. 10.15866/iremos.v8i1.5197 . hal-01154195

\author{
HAL Id: hal-01154195 \\ https://hal.science/hal-01154195
}

Submitted on 21 May 2015

HAL is a multi-disciplinary open access archive for the deposit and dissemination of scientific research documents, whether they are published or not. The documents may come from teaching and research institutions in France or abroad, or from public or private research centers.
L'archive ouverte pluridisciplinaire HAL, est destinée au dépôt et à la diffusion de documents scientifiques de niveau recherche, publiés ou non, émanant des établissements d'enseignement et de recherche français ou étrangers, des laboratoires publics ou privés. 


\title{
Smart Algorithm Based on the Optimization of SVR Technique by k- NNR Method for the Prognosis of the Open-Circuit and the Reversed Polarity Faults in a PV Generator
}

\author{
Wail Rezgui ${ }^{1}$, Nadia Kinza Mouss ${ }^{1}$, Leïla-Hayet Mouss ${ }^{1}$, \\ Mohamed Djamel Mouss ${ }^{1}$, Yassine Amirat ${ }^{2}$ and Mohamed Benbouzid ${ }^{3}$
}

\begin{abstract}
This paper deals with a new smart algorithm allowing open-circuit and reversed polarity faults prognosis in photovoltaic generators. Its contribution lies on the optimization of support vector regression (SVR) technique by a $k-N N$ regression tool $(k-N N R)$ for undetermined outputs.
\end{abstract}

To testing the performance of the proposed algorithm, we used a significant data base containing the generator functioning history, and as indicators we selected variance, standard deviation, Confidence interval, absolute and relative errors.

Keywords: Photovoltaic Generator, SVR, k-NNR, Open-Circuit, Reversed Polarity, Diagnosis, Prognosis, Lab-VIEW.

$\begin{array}{ll}P V & \text { Photovoltaic } \\ S V M & \text { Support Vector Machines } \\ S V R & \text { Support Vector Regression } \\ k-N N R & \text { k-Nearest Neighbor Regression } \\ X & \text { SVR input vector } \\ Y & \text { SVR output vector } \\ f & \text { Linear function } \\ \Phi & \text { Nonlinear mapping function } \\ w & \text { Weight vector } \\ e & \text { Squared loss function } \\ x & \text { Problem variable } \\ x & \text { New problem variable } \\ \alpha & \text { Lagrange multipliers } \\ N & \text { Number of classes } \\ m & \text { Number of index of minimum distances } \\ I / V & \text { Current / Voltage } \\ I P H & \text { Photocurrent }\end{array}$

\section{Introduction}

The performance index is a value independent of place and measuring the PV system production [1]-[3]. Really, this performance index is often called the quality factor. It indicated as a percentage, means the ratio between the actual and the theoretical PV system energy. So, it shows the share of the available actually energy, after deducting the specific operating consumption by the installation, and the energy losses (thermal and conduction losses).

So, these energy losses can be caused by the presence of defects, like the open-circuit and reversed polarity. However, provided a better prognosis [9]-[12] and diagnosis [14]-[16] functions of the generator can stabilize its performance and ensure its availability and reliability.

In this context, the paper objective is the development of an algorithm for the prognosis of a photovoltaic generator state, under open-circuit and reversed polarity faults. Indeed, the paper contributions are twofold: 1) development an algorithm for the detection and the localization of the open-circuit and reversed polarity faults at the PV generator components: cells, bypass and blocking diodes, it bases on the analysis of the operating parameters of the generator. 2) Development of a smart prognosis algorithm for the characterization of the open-circuit and reversed polarity faults, regardless of their localization. It bases on the support vector regression (SVR) [19]-[22] optimized by the k-nearest neighbor method [23]-[26].

\section{Classical Diagnosis Algorithm}

This new proposed algorithm is for objective to detecting and locating the open-circuit and reversed polarity faults on the generator components: PV cells, bypass and blocking diodes.

The following figure shows the studied generator (Fig.1), which contains five strings in parallel, where each string comprises five modules in series, and ended by blocking diode. Each module contains two groups in series. Finally, each group composes of eighteen cells in series regrouped by one bypass diode in parallel.

This new proposed algorithm consist mainly four steps: 


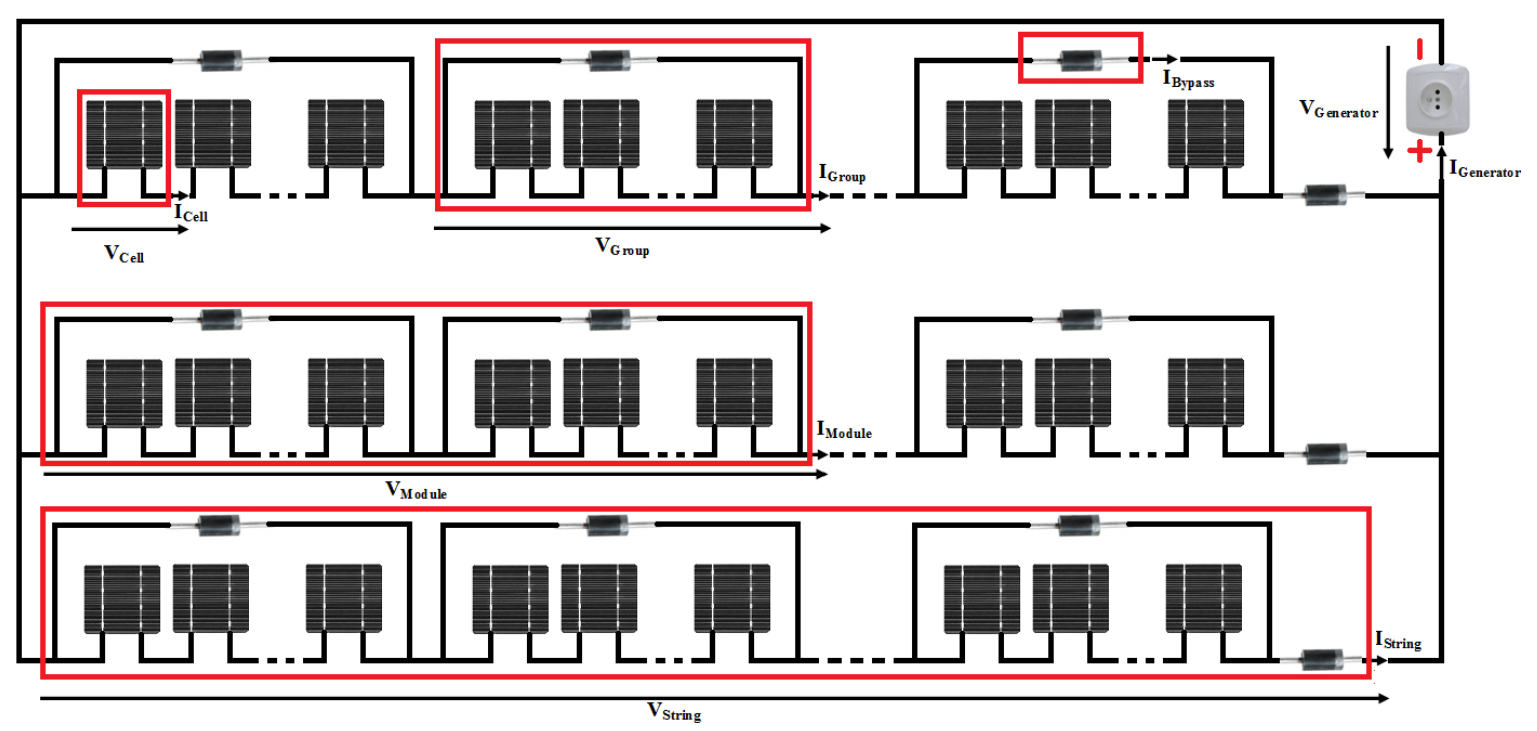

Fig.1 . Photovoltaic generator described

A) Step 1: if the generator characteristic is

$\left\{\begin{array}{l}V_{P V}=V_{P V_{-} \text {open-Circuit }} \\ I_{P V}=0\end{array}\right.$

indicates that the generator is open-circuit. But, if its characteristic is

$$
\left\{\begin{array}{l}
0 \leq V_{P V} \leq V_{P V_{-} o_{p p o s i t e}} \\
-I_{P V_{-} O_{p p o s i t e}} \leq I_{P V} \leq 0 \\
P H I=0
\end{array}\right.
$$

mains that the generator is subjected to a reversed polarity fault. Also, if its characteristic is

$$
\left\{\begin{array}{l}
-V_{P V_{-} \text {Healthy }} \leq V_{P V} \leq V_{P_{-} \text {Healthy }_{1}} \\
0<I_{P V}<I_{P V_{-} \text {Healthy }} \\
P H I \neq 0
\end{array}\right.
$$

designates that the generator contains at least one string with components in reversed polarity fault.

B) Step2: if the string characteristic is

$\left\{\begin{array}{l}V_{\text {String }}=V_{\text {String_open-Circuit }} \\ I_{\text {String }}=0\end{array}\right.$

indicates the presence of at least one of these defects: connections between modules open-circuit, blocking diode open-circuit or modules open-circuit. But, if its characteristic is

$$
\left\{\begin{array}{l}
I_{\text {String_Cells }}=0 \\
I_{\text {String }}=I_{\text {String_opposite }}<0 \\
P H I=0 \\
V_{\text {String }}=V_{\text {String_opposite }}
\end{array}\right.
$$

mains that its blocking diode under reversed polarity. Also, if its characteristic is

$$
\left\{\begin{array}{l}
0<I_{\text {String }}<I_{\text {String_Healthy }} \\
-V_{\text {String_Healthy }} \leq V_{\text {String }} \leq V_{\text {String_Healthy }} \\
I_{\text {String_opposite }}=0 \\
I P H \neq 0
\end{array}\right.
$$

designates that this string contains at least one module under reversed polarity.

C) Step3: if the module characteristic is

$$
\left\{\begin{array}{l}
I_{\text {Module }}=0 \\
V_{\text {Module }}=V_{\text {Module_open-circuit }}
\end{array}\right.
$$

mains the presence of at least one of group open-circuit, or connection between groups open-circuit. But, if its characteristic is

$$
\left\{\begin{array}{l}
0<I_{\text {Module }}<I_{\text {Module_Heathy }} \\
-V_{\text {Module_Heathy }}<V_{\text {Module }}<V_{\text {Module_Healthy }}
\end{array}\right.
$$

designates the presence of module in reversed polarity.

D) Step4: the PV group is open-circuit if

$$
\left\{\begin{array}{l}
I_{\text {Group }}=0 \\
V_{\text {Group }}=V_{\text {Group_open circuit }}
\end{array}\right.
$$

Also, if its characteristic is

$\left\{\begin{array}{l}I_{\text {Group }} \neq 0 \\ V_{\text {Group }}=V_{\text {Group_open-Circuit }}\end{array}\right.$

designates the existence of cells open-circuit, Or connections between cells open-circuit. In addition, if its characteristic is 


$$
\left\{\begin{array}{l}
I_{\text {Group }}=0 \\
V_{\text {Group }}=0 \\
I P H=0
\end{array}\right.
$$

indicates that this group contains a bypass diode opencircuit. But, if the group characteristic is

$$
\left\{\begin{array}{l}
I_{\text {Group }}=I_{\text {Group_Healthy }} \\
0<V_{\text {Group }}<V_{\text {Group_Healthy }}
\end{array}\right.
$$

mains the presence of group contains at least cell under reversed polarity, with the number of healthy cells is greater than the defective ones. Also, if its characteristic is

$$
\left\{\begin{array}{l}
I_{\text {Group }}=I_{\text {Cells }}+I_{\text {Bypass diode }} \\
-V_{\text {Cells_Healthy }} \leq V_{\text {Group }} \leq 0
\end{array}\right.
$$

designates the existence of group contains at least half of its cells under reversed polarity. And finally, if its characteristic is

$$
\left\{\begin{array}{l}
I_{\text {Group }}=I_{\text {Cells__Healthy }}-I_{\text {Bypass diode }} \\
V_{\text {Group }}=0
\end{array}\right.
$$

Indicates that this group is grouped by a bypass diode in reversed polarity.

\section{Intelligent Prognosis Algorithm}

\section{III.1. SVR Algorithm}

Regression by support vector machines (Support Vector Regression) is an extension of support vector machines developed by the VAPNIK group. The purpose of this approach is to determine the optimal hyper-plane representing the dataset. This hyper-plane must interpolate the observations with some margin, which defined by the insensitivity loss function. The main advantages of this approach are its robustness against noise and errors, also the possibility of its use in the nonlinear case through the kernel functions.

Consider a set of data: $\left\{\left(x_{1}, y_{1}\right), \ldots,\left(x_{n}, y_{n}\right)\right\} \subset X$, where $X$ represents the data space. In support vector regression, the objective is to find the function $f(x)$, which has at most a deviation of $\varepsilon$, compared to the $y_{i}$ targets of all dataset, and at the same time which is flat as possible.

SVR general pattern of regression in its linear and nonlinear cases is as follows

$$
\left\{\begin{array}{l}
\text { If the problem is linearly separable } \\
\quad f(x)=\langle w, x\rangle+b \\
\text { Else } \\
\quad f(x)=\langle w, \phi(x)\rangle+b
\end{array}\right.
$$

The aim therefore at this point is to determine the function parameters, which is the weight $w$, and the bias $b$, which minimize the SVR margin, this leads to a least squares to simplify the SVR problem to a system of linear equalities. The regression problem becomes then as follows.

$\left\{\begin{array}{l}\text { If the problem is linearly separable } \\ \quad f(x)=\left[\left\langle x, x_{1}\right\rangle\left\langle x, x_{2}\right\rangle \ldots\left\langle x, x_{N}\right\rangle\right] \alpha+b \\ \text { Else } \\ \qquad f(x)=\left[\left\langle\phi(x), \phi\left(x_{1}\right)\right\rangle \ldots\left\langle\phi(x), \phi\left(x_{N}\right)\right\rangle\right] \alpha+b\end{array}\right.$

As all regression techniques, this tool has some disadvantages that can degrade its effectiveness, among them the existence of indeterminate outputs for some observations. The outputs of the regression model are generally of good quality when they are determinate.

Consequently, we are proposed and after a research bibliography interesting as solution the k-nearest neighbors, thanks to its advantages in the regression area. The use of this tool is for the outputs approximations of these some observations have indeterminate outputs by SVR.

\section{III.2. $k$-NN Regression Algorithm}

$k-N N$ is a method based on memory, which unlike other statistical methods does not require any learning (that is to say there is no model to adjust). It belongs to the Prototypes methods category. It operates on the intuitive principle, which the nearest objects are most likely to belong to the same category. Thus, with the $k$ $N N$ method, the forecasts are based on a set of prototypes examples, which are used to predict new data, based on the average for the regression of the $k$ nearest prototypes.

The choice of $k$ is essential in the $\mathrm{k}-\mathrm{NN}$ model construction, because it can strongly influence the forecasts quality. For a given problem, a low value of $k$ will lead to a large variance in the forecast. Contrary, if you assign a high $k$ value, you will introduce significant bias in the model, because it can minimize the regression error probability.

After selecting the $k$ value, the forecasts assignment is based on the examples of k-NN. For regression problems, forecasts k-NNs are calculated as the average of the $k$ nearest neighbors.

$y=\frac{1}{k} \sum_{j=1}^{k} y_{i}$

Where $y_{i}$ is the $i^{\text {th }}$ sample observation of examples, and $y$ is the forecast (result) of the query point. 


\section{III.3. The Proposed Smart Algorithm}

In this section, we proposed a new smart algorithm allowing smart prognosis of a PV generator. This new model is firstly used SVR technique bases on its kernel function on Gaussien type, for all observations have determined outputs. And secondly, it used k-NNR tool that aims to approximate the observations outputs that have undetermined outputs predict by SVR technique. The hybridization of these two methods leads to the following formulation.

If the problem is linearly separable
$f(x)=(1-\theta)\left(\begin{array}{l}\left.\left[\left\langle x, x_{1}\right\rangle\left\langle x, x_{2}\right\rangle \ldots\left\langle x, x_{N}\right\rangle\right] \alpha+\right) \\ {\left[y_{i}-e_{i}-\left\langle w, x_{i}\right\rangle\right]}\end{array}\right)+\theta \frac{\sum_{p=1}^{m}\left(\left[\begin{array}{l}\left.\left.\left[x_{\left[\text {index }_{p}\right]}, x_{1}\right\rangle\left\langle x_{\left[\text {index }_{p}\right]}, x_{2}\right\rangle \ldots\left\langle x_{\left[\text {index }_{p}\right]}, x_{N}\right\rangle\right] \alpha+\right) \\ {\left[y_{i}-e_{i}-\left\langle w, x_{i}\right\rangle\right]}\end{array}\right)\right.}{m}$

Else

$f(x)=\left[\begin{array}{r}(1-\theta)\left(\left[\left\langle\phi(x) \phi\left(x_{1}\right)\right\rangle\left\langle\phi(x) \phi\left(x_{2}\right)\right\rangle \ldots\left\langle\phi(x) \phi\left(x_{N}\right)\right\rangle\right] \alpha+\left[y_{i}-e_{i}-\left\langle w, \phi\left(x_{i}\right)\right\rangle\right]\right) \\ \left.+\theta\left(\frac{\sum_{p=1}^{m}\left(\left[\left\langle\phi\left(x_{\left[\text {index }_{p}\right]}\right) \phi\left(x_{1}\right)\right\rangle\left\langle\phi\left(x_{\left[\text {index }_{p}\right]}\right) \phi\left(x_{2}\right)\right\rangle \ldots\left\langle\phi\left(x_{\left[\text {index }_{p}\right]}\right) \phi\left(x_{N}\right)\right\rangle\right] \alpha+\left[y_{i}-e_{i}-\left\langle w, \phi\left(x_{i}\right)\right\rangle\right]\right)}{m}\right]\right)\end{array}\right]$

$\theta=0$ for determined SVR results, else $\theta=1 . \mathrm{i}=1: 1: \mathrm{N}$.

\section{Simulations Results}

\section{IV.1. Faulted PV Generator Characterization}

The results simulations of classical diagnosis algorithm by Lab-VIEW software are shown in the following Figs. 2 to 7.

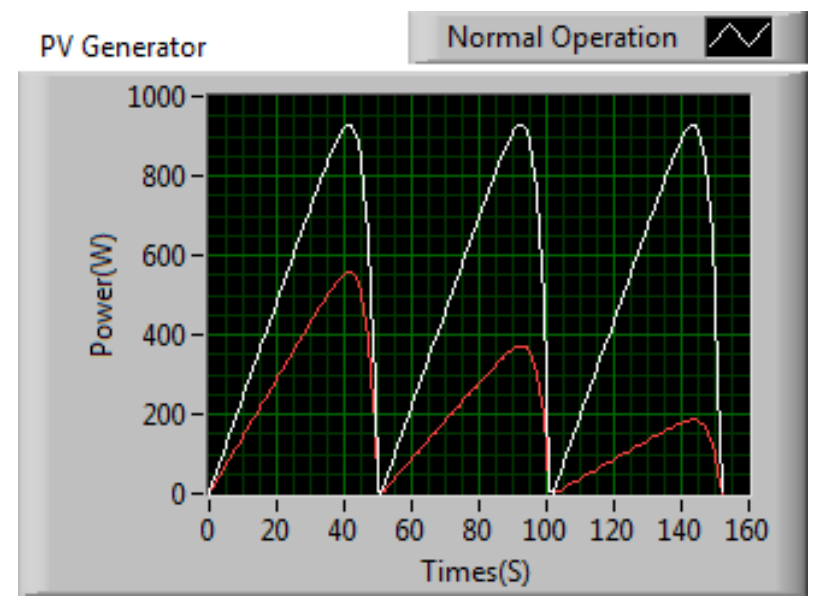

Fig2. Open circuit cells influence on the PV generator operation.

1) Fig. 2 presents the future operation of the defective PV generator subjected successively to 1, 2, 3 defective groups, where everyone contains a cell open-circuit. It shows that the open-circuit influence is not remarkable on the generator current, except where one of its strings all its groups are defective. But, it can increase the generator voltage, if all its strings are defective, and it increased in proportion to the increase in the number of its faulty groups, until it reaches its open-circuit value, and its current becomes zero.

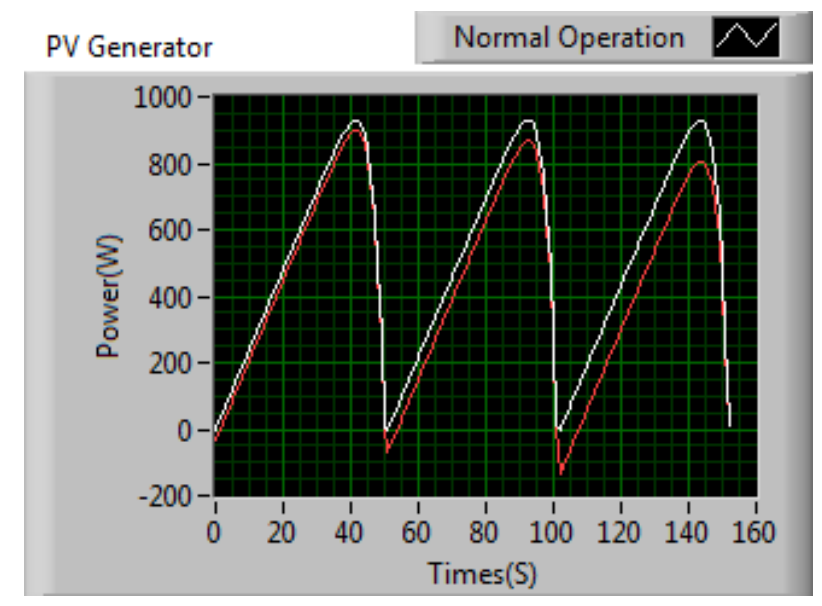

Fig3. Cells reversed polarity influence on the PV generator operation.

2) Fig. 3 presents the future operation of the PV generator in the presence of successively $5,10,15$ cells reversed polarity. It shows that the generator power decreases proportionally to the number of defective cells, until will be null in the case where half of its cells are defective. Also, the PV generator absorbs power if the number of its defective cells greater that the healthy ones.

3) Fig. 4 shows an operating mode of the faulty PV generator with a power output as the normal operation, but it subjected to the presence of successively 10, 20, 50 bypass diodes reversed polarity. Therefore, the absence of the photocurrent on the last group of each string in the third phase of the PV generator operation discovers the 
presence of bypass diodes open-circuit. Consequently, the bypass diode open-circuit defect is classified among the major flaws, because its detection is difficult and requires to other parameters such as the sunlight. So, we concluded that the influence of this defect is not remarkable on the characterization of the generator, as long as the cells group assembled by these defective diodes is in the normal functioning.

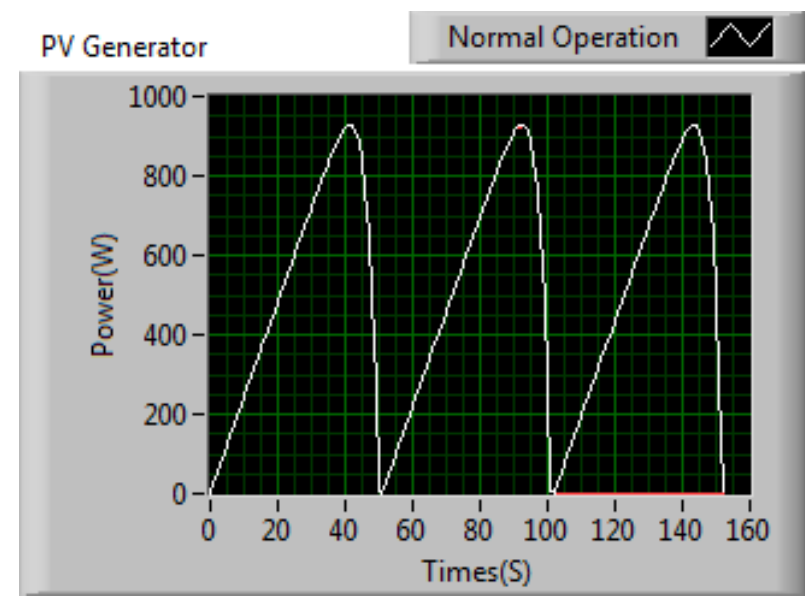

Fig4. Open circuit bypass diodes influence on the PV generator operation.

4) Fig. 5 shows the presence influence of successively 2, 3, 8 faulty groups, where each one contains one bypass diode reversed polarity on the future operation of the PV generator. It shows that the bypass diode reversed polarity has a greater impact on the PV generator performance, because it can cancel outright its group voltage.

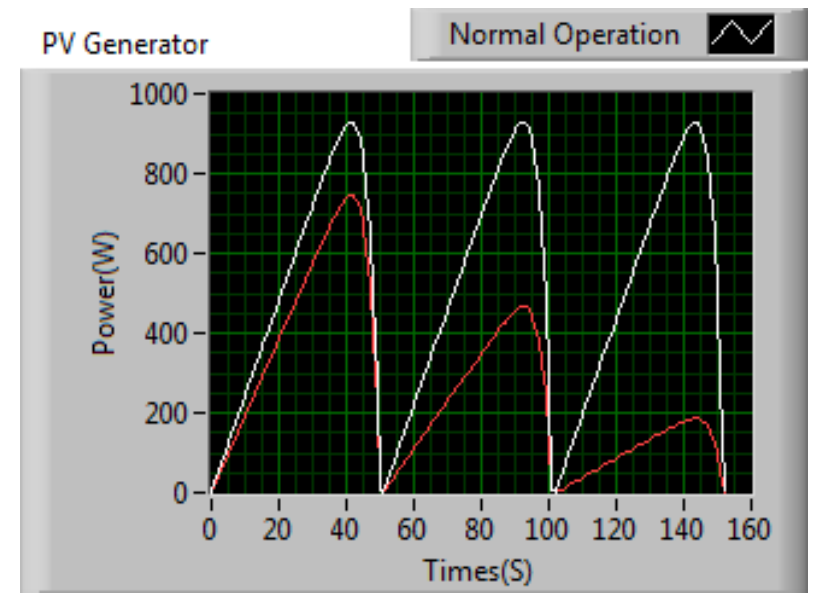

Fig5. Bypass diodes reversed polarity influence on the PV generator operation

Fig. 6 shows the future operation of PV generator contains successively the presence of $2,3,4$ defective blocking diodes open-circuit. It shows that the opencircuit defect can cut the current flowing across the faulty string, and therefore increases its voltage to its open-circuit value. Its influence is not remarkable on the generator voltage contains at least one good string, but its current is reduced in proportion to the increase in the number of blocking diode open-circuit, up to becomes zero, thereby its voltage takes its open-circuit value.

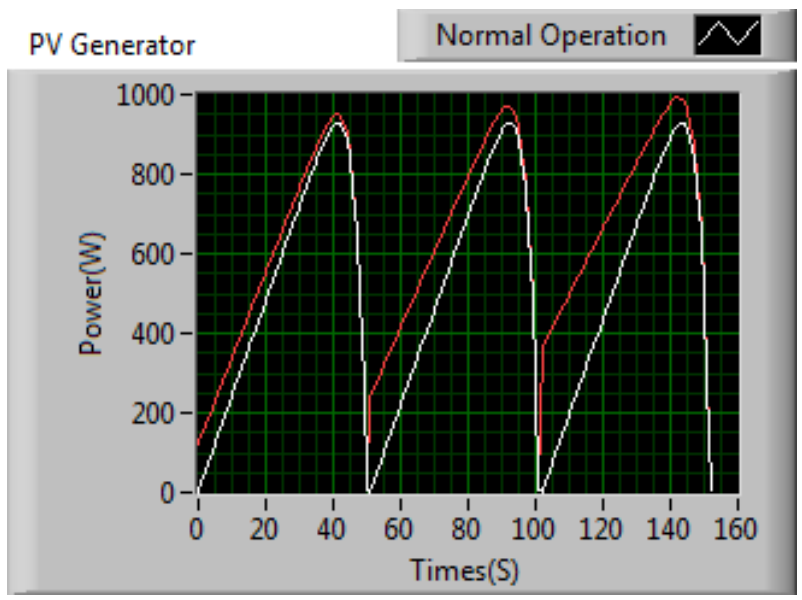

Fig6. Blocking diode open circuit influence on the PV generator operation.

Fig. 7 presents the case of the presence of successively 1, 2, 3 blocking diodes reversed polarity in the future operation of the PV generator. It shows that the reversed polarity defect can degrade the generator power, because the existence of one defective blocking diode can affect the string current flow, and this string behaves in the open-circuit mode.

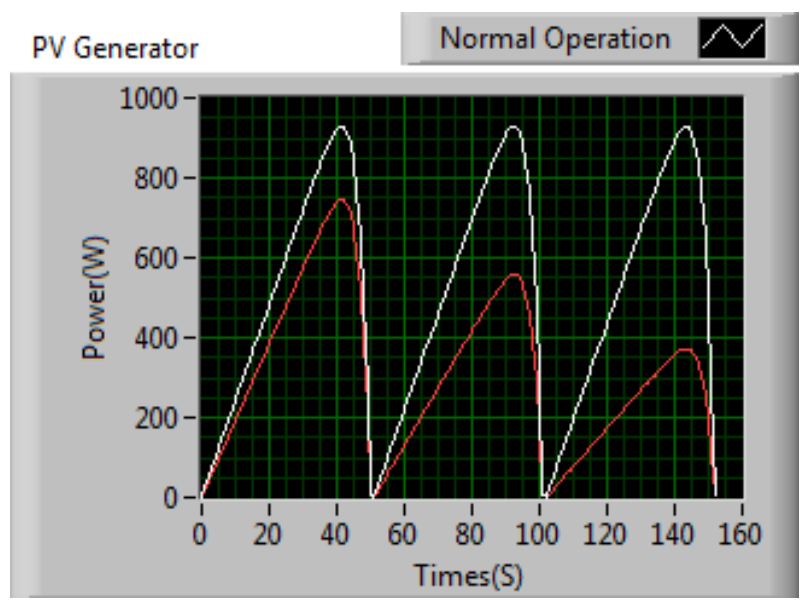

Fig7. Blocking diode reversed polarity influence on the PV generator operation.

\section{IV.2. Smart Algorithm Tests}

In this context, three 50 identical samples are selected (total sum $=150$ samples), each sample containing 950 observations, each observation constituted six parameters which are: current $I$, voltage $V$, power $P$, series resistance $R_{s}$, temperature $T$ and photocurrent $I_{p h}$, but this observation is presented in this simulation by its center of gravity ' $x$ ', so the 47500 observations (50 samples * 950 observations) are distributed on four classes types which are: normal functioning, cells open-circuit and reversed polarity, bypass diodes open-circuit and reversed polarity and finally blocking diodes open-circuit and reversed polarity [27]-[28]. In this application, we are used for each 50 samples one of the three regression 
tools used for comparison purposes: SVR, k-NNR, and the proposed model SVR optimized by k-NNR.
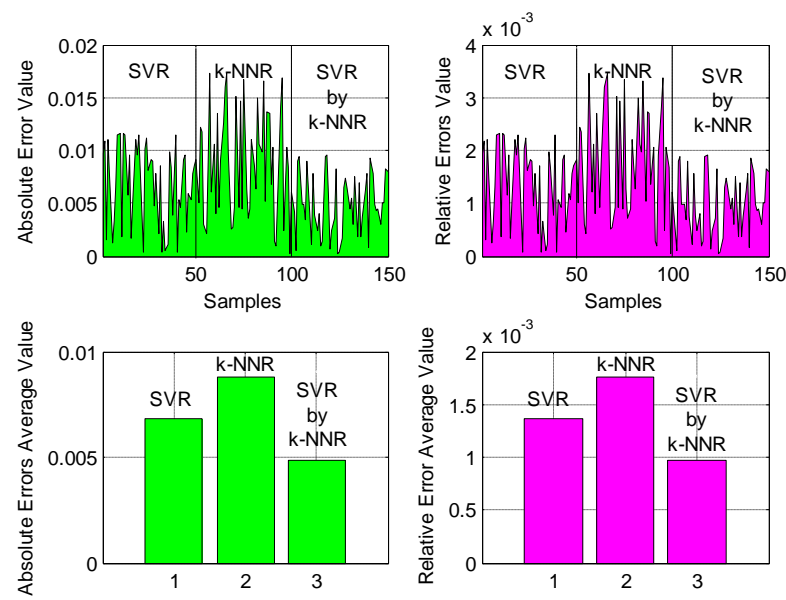

Fig. 8. Absolute and relative errors vs prediction tools.
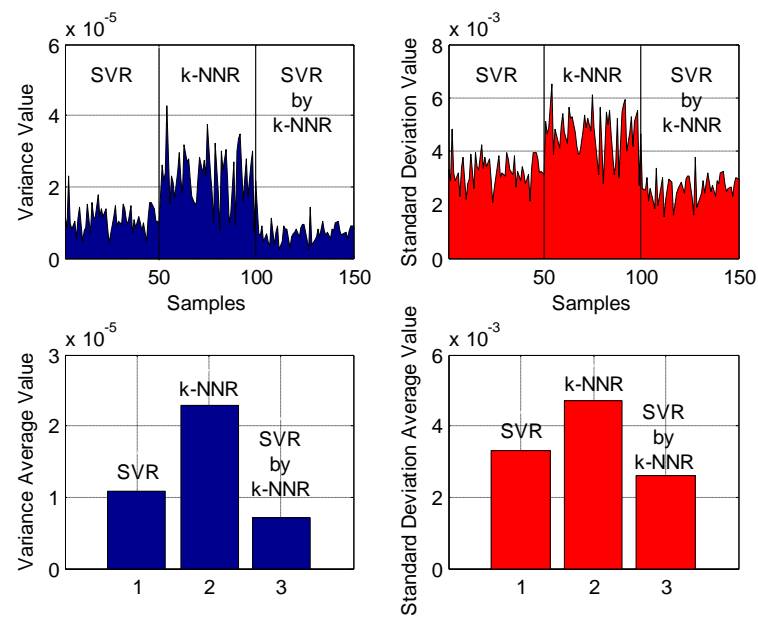

Fig. 9. Variance and standard deviation vs prediction tools.
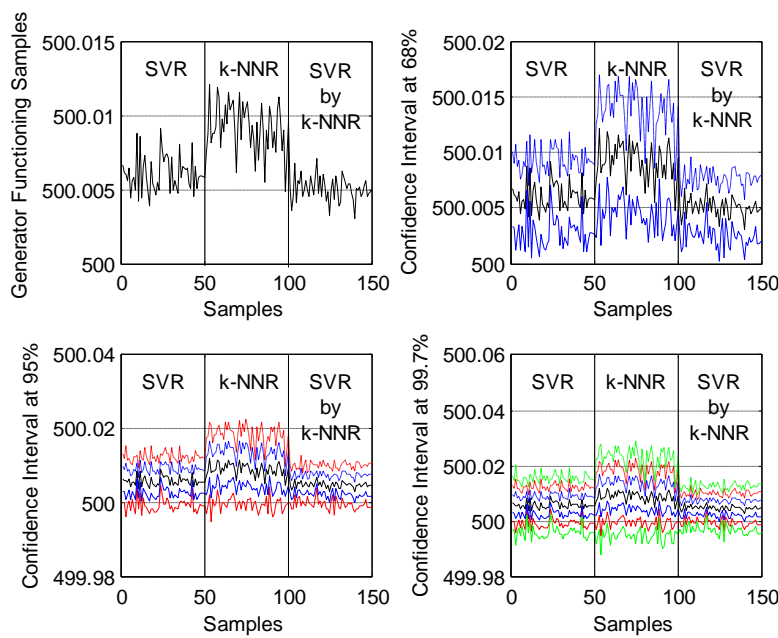

Fig. 10. Confidence interval vs prediction tools.

Fig. 8 illustrates the prediction performance in terms of absolute and relative errors. It shows that the k-NNR has a greater absolute and relative error. Then, in a descending orders successively the SVR tool, and finally the proposed model that provides the smallest absolute and relative error in these all tools. This means that the proposed model achieves the best prediction performance.

Fig. 9 illustrates the second criterion used for the prediction performance evaluation: variance and standard deviation. It shows that the k-NNR has the greater standard deviation and variance. Then, in a descending orders successively SVR, and finally the proposed model, which has a smallest standard deviation and variance. This means that the predicted results of the proposed method are more homogeneous.

The third evaluation criterion used is the confidence interval. In this case, Fig. 10 shows that the k-NNR provides a larger confidence interval, then SVR tool, then finally the proposed model that has the confidence interval the most optimized. This means that the predicted results of the proposed method are more reliable.

\section{Conclusion}

In this article, we are proposed a new smart prognosis algorithm for the open-circuit and reversed polarity faults, in a photovoltaic generator. The proposed prognosis (prediction) approach is based on the use of SVR tool, optimized by k-NNR for undetermined outputs.

The study and analysis of the results obtained from the simulation based on the determination of the absolute and relative error, standard deviation and variance, and finally the confidence margin, shows that the new contribution achieves the best prediction performance with more homogeneous and reliable prediction results.

The future work of this algorithm lies in the prognosis of the hybridization of the two defects opencircuit and reversed polarity, which can present at the same component and in the same time.

\section{References}

[1] Z.M. Zain, M.I. Yusof, M.Z. Hussin, N.Y.Dahlan, L.A.Rimon, Grid connected monocrytalline and polycrystalline photovoltaic system: A comparative study on performance, in Proceedings of the 2013 IEEE ICSPC (Conference on Systems, Process \& Control), pp. 275 - 278, Kuala Lumpur, 13-15 Dec. 2013.

[2] J.S. Stein, The photovoltaic Performance Modeling Collaborative (PVPMC), in Proceedings of the 2012 IEEE PVSC $\left(38^{\text {th }}\right.$ Photovoltaic Specialists Conference), pp. 003048 - 003052, Austin, TX, 3-8 June 2012.

[3] J. Fali, F. Xiangzhao, Research on impact of dust on solar photovoltaic(PV) performance, in Proceedings of the 2011 IEEE ICECE (International Conference on Electrical and Control Engineering), pp. 3601 - 3606, Yichang, 16-18 Sept. 2011.

[4] R. Iannone, S. Miranda, S. Riemma, G. Spagnuolo, An Integrated Approach to the Simulation/optimization of Grid-connected Photovoltaic Systems: the Rational Choice of Components, 
International Review of Electrical Engineering (IREE), Vol. 7, n. 3, pp. 4596-4606, June 2012.

[5] Y. Riffonneau, S. Bacha, F. Barruel, Y. Baghzouz, E. Zamaï, Optimal Reactive Supervision of Grid Connected PV Systems with Batteries in Real Conditions, International Review of Electrical Engineering (IREE), Vol. 7. n. 3, pp. 4607-4615, June 2012.

[6] R. M. Essefi, M. Souissi, H. H. Abdallah, Current Control Strategy for Grid Connected Photovoltaic Inverter via LCL Filter, International Review on Modelling and Simulations (IREMOS), Vol 6, n. 5, pp. 1426-1434, 2013.

[7] M. Guisser, M. Aboulfatah, E. Abdelmounim, A. El jouni, Nonlinear MPPT Controller for Photovoltaic Pumping System Based on Robust Integral Backstepping Approach, International Review on Modelling and Simulations (IREMOS), Vol 7, n. 3, pp. 481-488, 2014.

[8] R. M. Essefi, M. Souissi, H. H. Abdallah, Intelligent Approach to Maximum Power Point Tracking Control Strategy for Photovoltaic Generation Systems, International Review on Modelling and Simulations (IREMOS), Vol 7, n. 2, pp. 287-297, 2014.

[9] W. Rezgui, L.H. Mouss, N.K. Mouss, M.D. Mouss and M.E.H. Benbouzid, «A Regression Algorithm for the Smart Prognosis of a Reversed Polarity Fault in a Photovoltaic Generator», in Proceedings of the 2014 IEEE ICGE, Sfax (Tunisia), pp. 1-5, March 2014.

[10] W. Rezgui, L.H. Mouss, N.K. Mouss, M.D. Mouss, Y. Amirat and M.E.H. Benbouzid, « Development of a smart algorithm for the prognosis and the diagnosis of the short circuit and the reversed polarity faults in a photovoltaic generator», in Proceedings of the 2014 ICIEM, Batna (Algeria), May 2014.

[11] S.S.H. Zaidi, W.G. Zanardelli, S. Aviyente, E.G. Strangas, Prognosis of electrical faults in permanent magnet AC machines using the hidden Markov model, in Proceedings of the 2010 IEEE IECON $\left(36^{\text {th }}\right.$ Annual Conference on IEEE Industrial Electronics Society), pp. 2634 - 2640, Glendale, AZ, 7-10 Nov. 2010.

[12] W. Rezgui, L. H. Mouss, M. D. Mouss, O. KADRI and A. DISSA, «Electrical faults detection for the intelligent diagnosis of a photovoltaic generator », Journal of Electrical Engineering, Vol. 14, Issue. 1, pp. 77-84, March 2014.

[13] W. Rezgui, L.H. Mouss, N.K. Mouss, M.D. Mouss and M.E.H. Benbouzid, «A smart algorithm for the diagnosis of short-circuit faults in a photovoltaic generator ", in Proceedings of the 2014 IEEE ICGE, Sfax (Tunisia), pp. 1-5, March 2014.

[14] W. Rezgui, L.H. Mouss, N.K. Mouss, M.D. Mouss, Y. Amirat and M.E.H. Benbouzid, «Optimization of SVM Classifier by kNN for the Smart Diagnosis of the Short-Circuit and Impedance Faults in a PV Generator », International Review on Modelling and Simulations (IREMOS), Vol.7, Nº5, pp. 863-870, May 2014.

[15] Hirata Y, Noro S, Aoki T, Miyazawa S, Diagnosis photovoltaic failure by simple function method to acquire $\mathrm{I}-\mathrm{V}$ curve of photovoltaic modules string, in the proceeding of 2012 IEEE PVSC ( $38^{\text {th }}$ Photovoltaic Specialists Conference), pp. $001340-$ 001343, Austin, TX, 3-8 June 2012.

[16] Gonzalez M, Raison B, Bacha S, Long Bun, Fault diagnosis in a grid-connected photovoltaic system by applying a signal approach, in the proceeding of 2011 IEEE IECON (37 $7^{\text {th }}$ Annual Conference on IEEE Industrial Electronics Society), pp. 1354 1359, Melbourne, VIC, 7-10 Nov. 2011.

[17] Tang Jianeng, Zhu Yongqiang, Wang Wenshan, Fault diagnosis method and simulation analysis for photovoltaic array, in the proceeding of 2011 IEEE ICECE (International Conference on Electrical and Control Engineering), pp. 1569 - 1573, Yichang, 16-18 Sept. 2011.

[18] Xiaoli Xu, Huan Wang, Yunbo Zuo, Method for Diagnosing Photovoltaic Array Fault in Solar Photovoltaic System, in the proceeding of 2011 IEEE APPEEC (Asia-Pacific Power and Energy Engineering Conference), pp. 1 - 5,.Wuhan, 25-28 March 2011.

[19] H. Zhao, Y. Zhang, E-P. Li, A. Buonanno, M. D'Urso, Diagnosis of Array Failure in Impulsive Noise Environment Using Unsupervised Support Vector Regression Method, IEEE
Transactions on Antennas and Propagation, Vol. 61, Issue. 11, pp. $5508-5516$, Nov. 2013.

[20] S. Duan, Q. Li, Y. Zhao, Fault diagnosis for sensors of aeroengine based on improved least squares support vector regression, in Proceedings of the 2011 IEEE FSKD (Eighth International Conference on Fuzzy Systems and Knowledge Discovery), pp. 1962 - 1966, Shanghai, 26-28 July 2011.

[21] W-J. Tian, J-C. Liu, Fault diagnosis analysis with support vector regression and particle swarm optimization algorithm, in Proceedings of the 2010 IEEE CCDC (Chinese Control and Decision Conference), pp. 3370 - 3374, Xuzhou, 26-28 May 2010.

[22] W-J. Tian, J-C. Liu, Fault diagnosis model research based on support vector regression and principal components analysis, in Proceedings of the 2010 IEEE CCDC (Chinese Control and Decision Conference), pp. 3896 - 3899, Xuzhou, 26-28 May 2010.

[23] C. Guillemot, S. Cherigui, D. Thoreau, K-NN search using local learning based on regression for neighbor embedding-based image prediction, in Proceedings of the 2013 IEEE ICASSP (International Conference on Acoustics, Speech and Signal Processing), pp. 2006 - 2010, Vancouver, BC, 26-31 May 2013.

[24] M. Luo, Y. Zheng, S. Liu, Data-based fault-tolerant control of the semiconductor manufacturing process based on K-nearest neighbor nonparametric regression, in Proceedings of the 2012 IEEE WCICA $\left(10^{\text {th }}\right.$ World Congress on Intelligent Control and Automation), pp. 3008 - 3012, Beijing, 6-8 July 2012.

[25] F. Farahnakian, T. Pahikkala, P. Liljeberg, J. Plosila, Energy Aware Consolidation Algorithm Based on K-Nearest Neighbor Regression for Cloud Data Centers, in Proceedings of the 2013 IEEE UCC (6th International Conference on Utility and Cloud Computing), pp. 256 - 259, Dresden, 9-12 Dec. 2013.

[26] F.H. Al-Qahtani, S.F. Crone, Multivariate k-nearest neighbour regression for time series data - A novel algorithm for forecasting UK electricity demand, in Proceedings of the 2013 IEEE IJCNN (International Joint Conference on Neural Networks), pp. 1 - 8, Dallas, TX, 4-9 Aug. 2013.

[27] W. Rezgui, L.H. Mouss, M.D Mouss, «Modeling of a photovoltaic field in malfunctioning ", in Proceedings of the 2013 IEEE CoDIT (International Conference on Control, Decision and Information Technologies), Hammamet (Tunisia), pp. 788 - 793, 6-8 May 2013.

[28] W. Rezgui, L.H. Mouss, N.K. Mouss, M.D. Mouss, Y. Amirat and M.E.H. Benbouzid, «Electrical faults modeling of the photovoltaic generator », International Review on Modelling and Simulations (IREMOS), Vol.7, N², pp. 245-257, May 2014.

[29] X-F. Xiong, W. Zheng, K. Chen, Z-J. Shen, Identification Approach in Modeling a Photovoltaic Grid-Tie Inverter, International Review of Electrical Engineering (IREE), Vol. 7. $\mathrm{n}$. 3, pp. 4575-4584, June 2012.

[30] Mohamed Mostefai, Abdellah Miloudi, Yahia Miloud, An Intelligent Maximum Power Point Tracker for Photovoltaic Systems Based on Neural Network, International Review on Modelling and Simulations (IREMOS), Vol. 6, n. 5, pp. 14771481, 2013.

[31] Mahdaoui Rafik, Mouss Leila Hayet, Mouss Med Djamel, Chouhal Ouahiba Temporal Neuro-Fuzzy Systems in Fault Diagnosis and Prognosis, International Review on Modelling and Simulations (IREMOS), Vol. 4. n. 1, pp. 436-440, February 2011.

[32] Abdo Abou Jaoude, Khaled El-Tawil, Seifedine Kadry, Hassan Noura, Mustapha Ouladsine, Analytic Prognostic Model for a Dynamic System, International Review of Automatic Control (I.RE.A.CO), Vol. 3. n. 6, pp. 568-577, November 2010. 


\section{Authors' information}

${ }^{1}$ First author affiliation: Laboratory of Automation and Manufacturing, Batna Univerity, Rue Chahid Boukhlouf Batna Algeria.

${ }^{2}$ Second author affiliation: ISEN Brest, EA 4324 LBMS, Brest, France.

${ }^{3}$ Third author affiliation: University of Brest, EA 4325 LBMS, Rue de Kergoat, CS 93837, 29238 Brest Cedex 03, France.

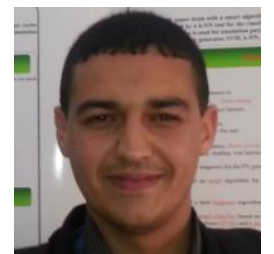

Wail REZGUI was born in N'gaous, Algeria, in 1987. He received his license in industrial engineering, industrial computer and Production option from Batna university between 2005- 2008, and his Master of Industrial Engineering, Industrial Computer and Production option, from university of Batna, between 2008- 2010. And finally he is currently pursuing Ph.D. studies on Industrial Engineering at the University of Batna.

Mr. REZGUI is member in the Automation and Manufacturing laboratory (LAP). His current research interests include diagnosis of photovoltaic systems using artificial intelligence techniques.

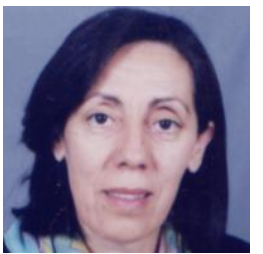

Leila Hayet Mouss was born in Batna, Algeria, in 1954. She received the B.Sc. degree in Electrical Engineering, in 1979, from the National Polytechnic School of Algiers, Algeria; the M.Sc. degree in Electrical and Computer Engineering, in 1982, from the ENSERB, France; and finally the Ph.D. degree also in Electrical and Computer Engineering, in 1985, Bordeaux University, France.

After graduation, she joined the University of Batna, Algeria, where she is an Associate Professor of Electrical and Computer Engineering. Pr. Mouss is a member of New York Science Academy. She is the head of Automatic and Computer Integrated Manufacturing Laboratory. Pr. Mouss current research interests include industrial Diagnosis of production system using the artificial intelligence techniques in the LAP Lab (Laboratory of Automation and Manufacturing) at Batna, Algeria.

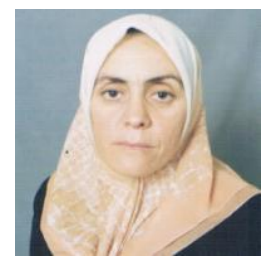

Kinza Nadia MOUSS was born in Batna, Algeria, in 1960. She received the B.Sc. degree in Electrical Engineering, in 1983, from the National Polytechnic School of Algiers, Algeria; the M.Sc. degree in Electrical and Computer Engineering, in 1984, from the ENSERB, France; and finally the Ph.D. degree also in Electrical and Computer Engineering, in 1986, Bordeaux University, France.

After graduation, she joined the University of Batna, Algeria, where she is a Professor of Electrical and Computer Engineering. Pr. Mouss is the head of Computer Integrated Manufacturing and supply chain management group. Pr. Mouss current research interests include industrial Supply Chain Management, Production system and Computer Integrated Manufacturing.

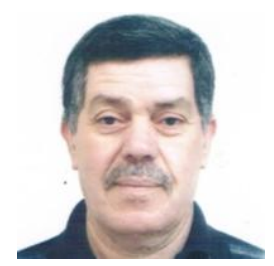

Mohamed Djamel MOUSS was born in Batna, Algeria, in 1956. He received the B.Sc. degree in Electrical Engineering, in 1982, from the National Polytechnic School of Algiers, Algiers, Algeria; the M.Sc. degree in Industrial Electricity and the Ph.D degree in Industrial Engineering, both from the University of Batna, Batna, Algeria, in 1989 and 2006, respectively; and the University Habilitation degree from the University of Batna, Batna, Algeria, in 2008.

After graduation, he joined the University of Batna, Batna, Algeria, where he is an Associate Professor of Electrical and Computer Engineering. Dr. Mouss is the leader of the $S^{3}$ team (Sûreté, Supervision, Surveillance) of the Automatic and Computer Integrated Manufacturing Laboratory (LAP). His current research interests include diagnosis of industrial production system using artificial intelligence techniques.

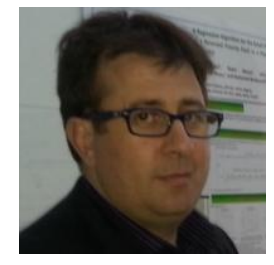

Yassine Amirat was born in Annaba, Algeria, in 1970. He received the B.Sc. and M.Sc. degrees in electrical engineering from the University of Annaba, Annaba, in 1994 and 1997, respectively. He is currently working toward the Ph.D. degree in wind turbine condition monitoring at the University of Brest, Brest, France. He is currently a Lecturer with the High Institute of Electronics and Numeric, Brest. His current research interests are the condition monitoring and the control of electrical drives and power electronics.

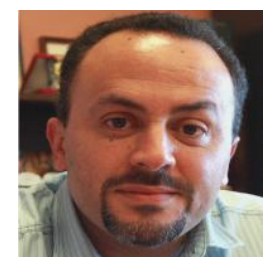

Mohamed El Hachemi Benbouzid was born in Batna, Algeria, in 1968. He received the B.Sc. degree in electrical engineering from the University of Batna, Batna, Algeria, in 1990, the M.Sc. and Ph.D. degrees in electrical and computer engineering from the National Polytechnic Institute of Grenoble, Grenoble, France, in 1991 and 1994, respectively, and the Habilitation à Diriger des Recherches degree from the University of Picardie "Jules Verne," Amiens, France, in 2000.

After receiving the Ph.D. degree, he joined the Professional Institute of Amiens, University of Picardie "Jules Verne," where he was an Associate Professor of electrical and computer engineering. Since September 2004, he has been with the Institut Universitaire de Technologie of Brest, University of Brest, Brest, France, where he is a Professor of electrical engineering. His main research interests and experience include analysis, design, and control of electric machines, variable-speed drives for traction, propulsion, and renewable energy applications, and fault diagnosis of electric machines.

Prof. Benbouzid is an IEEE Senior Member. He is the Editor-in-Chief of the International Journal on Energy Conversion (IRECON). He is also an Associate Editor of the IEEE TRANSACTIONS ON ENERGY CONVERSION, the IEEE TRANSACTIONS ON INDUSTRIAL ELECTRONICS, the IEEE TRansactions on Sustainable ENERgy, and the IEEE TRANSACTIONS ON VehicUlaR TeChNOLOGY. He was an Associate Editor of the IEEE/ASME TRANSACTIONS ON MECHATRONICS from 2006 to 2009 